\title{
BURGUESIA E PANDEMIA: NOTAS DE CONJUNTURA SOBRE NEOFASCISMO E ULTRANEOLIBERALISMO NO BRASIL DE BOLSONARO*
}

Felipe Demier

\section{A morte na esquina: Bolsonaro e a nossa agonia}

A morte foi solta, e nós fomos presos. Estamos presos. A cada dia, a cada hora, seu odor se torna mais intenso, porquanto mais próximo. Imparável, e mesmo desejado pelos sádicos do poder e da bolsa, seu espírito, o espírito da morte, torna-se carne, faz-se corpo, toma corpos e os leva ao mundo dos mortos, como se quisesse poupar muitos corações de um mundo sem coração, como se quisesse livrar logo muitas pessoas carentes dessa situação carente de vida, como se quisesse poupar de uma vez essas pobres almas de uma realidade social desalmada. Antes, só víamos a tragédia em parte, mas, com a pandemia, passamos a vê-la face a face.

A agonia cresceu, pois começou a ser ladeada por cadáveres, ou ao menos pelas notícias deles. A morte mora ao lado, e por isso as portas foram fechadas. No seu íntimo, no seu imo, o capital, em sua mórbida fase ultraneoliberal, quer abri-las, de modo que o mercado, com ou sem modos, faça, a seu modo, o serviço, escolhendo, como Deus mundano que é, quem deve ou não deixar esse mundo, tomado por caos, pandemia e falta da autêntica fé - a fé na vida. Mas se o íntimo dos ultraneoliberais não costuma vir à superfície diretamente, se as suas oníricas vontades normalmente são constrangidas por alguma fachada de razoabilidade, alguns de seus íntimos amigos, como os neofascistas, puderam e podem, no entanto, se encarregar de dizer e fazer o que deveria ser feito mas jamais dito, ou, pelo menos, não à luz do dia. Quando os desejos do mercado se traduziram em uma sociedade-necrotério, Bolsonaro não é mais do que a burguesia sem superego.

Mas, se às claras, Bolsonaro e os neofascistas, sob olhares críticos da grande imprensa, conjuram a morte, na calada da noite, por sua vez, Maia e os seus, como bons rapaces, porém tratados pela mesma imprensa como bons ra-

${ }^{*}$ DOI - 10.29388/978-65-86678-20-8-0-f.89-102 
pazes, roubam covardemente direitos de um povo prestes a perder de vez o direito à vida. "Aos bancos e a todos os homens de fortuna, tudo; aos desafortunados, miséria, morte e luto", é esse o adágio das nossas instituições e seus chefes que, se comparados aos milicianos, podem mesmo parecer impolutos. Mas só parecem. Alinhados com Guedes, os ilustres e "racionais" representantes de uma burguesia que há muito abandonou a ilustração, e que por aqui sempre temeu mais o povão do que amou a razão, aproveitam-se, tal qual gatunos, da fragilidade, da inércia e do medo de milhões para, em furtos noturnos, tira-lhes seus já escassos tostões. De modo vil e timorato, levaram assim o capitalismo ultraneoliberal de imediato ao encontro da profecia que diz que "a quem tem, mais se lhe dará, e terá em abundância; mas, ao que quase não tem, até o que tem lhe será tirado" (Cislaghi e Demier, 2019).

As tardes seguem caindo como viadutos sobre nós, nossos poetas seguem adoecendo e morrendo, as panelas anunciam a noite e extravasam um pouco a nossa repulsa ao horror, mas, enquanto amanhã ainda não for outro dia, e enquanto não tivermos ainda afastado de vez o temor, os dias seguirão amanhecendo com nossos celulares iniciando nossas rotinas lúgubres com anúncios fúnebres. O Brasil segue descendo a ladeira da morte e, progressivamente, os dados ganham identidade, rosto, carne e corpo, e os mortos passaram a ter nome, sobrenome, endereço, tendo sido gente pela qual nós tínhamos contato, amizade, amor e apreço. A morte, antes longínqua, periférica e severina, agora está na nossa esquina. Pretos, precarizados, periféricos. Pobres, quase todos pobres. Trabalhadores, milhares de trabalhadores. Uma ingente massa de gente que acabou e acabará, talvez, enterrada como indigente, em funerais apenas de corpos, já que nem os vivos estão podendo enterrar seus mortos, e nem mesmo os mortos de alma podem fazê-lo, deixando a cargo de Deus levar as marias, selmas e matheus.

Diante desse cenário, talvez valha a pena nos perguntarmos como chegamos até aqui.

\section{3-2018: os seis anos que modificaram o Brasil - para pior}

No dia 29 de abril de 2020, os meios de comunicação veicularam uma cena de populares que, no afã de conseguir leitos para seus familiares adoecidos, arrombaram com as próprias mãos as grades da entrada de um hospital, em Belém do Pará. Imediatamente, por óbvio, foram reprimidos pelos policiais no lo- 
cal, de modo que a uma primeira expressão da barbárie, a saber, gente morrendo às portas de um hospital fechado por superlotação, seguiram-se outras duas: o arrombamento do portão, que em nada ajudaria a resolver a dramática situação daquelas pobres pessoas e, depois, a indefectível e covarde repressão contra elas.

O tal desespero, que já foi moda em 1973, cantou certa feita um talentoso bardo, estava de novo em cena no país, mas então em proporções tão dantescas que infelizmente a cena do tal arrombamento foi apenas mais uma de uma cruenta sequência novelesca que, embora hoje protagonizada pela Besta presidencial, não começou a ser escrita durante a pandemia e nem por ele, e sim quando há algum tempo nossos roteiristas da Casa Grande decidiram tratar com manipulação e repressão um povo que implorava pelo direito de ter transporte, escola e um corpo são.

Há aproximadamente sete anos, milhares e milhares de brasileiros foram às ruas exigir mobilidade, educação e, sobretudo, saúde - sem a qual de pouco adiantam as outras duas eventuais conquistas. Conquanto politicamente desorganizadas e subjetivamente confusas, as massas deixaram claro o que queriam, e não queriam muito, convenhamos. Mas o pouco aqui, na periferia, para nossa burguesia, é sempre muito e, portanto, como já dissera Florestan Fernandes, as "revoluções por dentro da ordem" aqui se convertem objetivamente em "revoluções contra a ordem” (Fernandes, 1975).

Por meio da sua imprensa monopólica, nossos senhores da Casa Grande, que de pronto tinham rechaçado os protestos, aderiram a eles na mesma medida em que se acomodavam às suas formas ingenuamente inovadoras, adulteravam suas pautas programáticas e subvertiam seu conteúdo social e político. Com a incorporação aos atos dos rebanhos advindos das classes médias conservadoras, convocados pelo berrante do capital na telinha global, as Jornadas de Junho de 2013 logo se transformaram em "atos cívicos" contra uma obscura Proposta de Emenda Constitucional (PEC) que ninguém tinha ouvido falar, contra uma seletiva corrupção e contra a política como atividade humana.

Por trás da fachada de combate ao "sistema", uma retórica protofascista, que então reivindicava o aumento do poder do Ministério Público e dos juízes, não fazia senão fortalecer o mesmo sistema, o sistema capitalista e neoliberal, na medida em que despolitizava a política e fazia levedar os expedientes bonapartistas e coercitivos da democracia em crise, tornado o regime político cada vez mais adaptado às novas exigências da acumulação. De tanto dizer que as ruas pediam o que não estavam pedindo, a imprensa do capital conseguiu, finalmente, que, em parte, as ruas, agora já com bandeiras e camisas verde-amarelas, 
e com ataques aos de camisas vermelhas, pedissem o que ela queria que fosse pedido. O "combate à corrupção" implicava, assim, segundo os jornalistas do capital, a redução do Estado na economia (pois, segundo eles, onde há Estado há política, e onde há política há corrupção) e o fortalecimento de sua esfera judiciária-policial.

Destarte, a melodia burguesa com suas únicas duas notas seguia sendo tocada pela banda, ou melhor, pelos bandos que nos telejornais davam e dão voz à Banca. "Mais austeridade e mais repressão", eis a simples receita que é melíflua ao paladar do bom patrão. Os elementos centrais do projeto bonapartista que, por dentro, corroeriam nos anos seguintes a democracia blindada, já estavam ali. O roteiro parecia já alinhavado, mesmo que nem todos os seus personagens tivessem ainda entrado em cena. Para um povo que, nas origens do movimento, isto é, em sua fase autêntica, clamava por direitos sociais, portanto, desejava o aumento do investimento estatal nos serviços estatais, o governo Dilma ofereceu um pacto vertebrado por cinco pontos, cujo primeiro era justamente a manutenção da austeridade fiscal; dizendo que ouvia a voz das ruas, nossa anêmica social-democracia, sempre cedendo à nossa mórbida burguesia, respondeu ao povo tal qual um surdo a alguém que berra o seu nome, portando-se de forma tão insensata como um sujeito que oferece um banho de sol a um outro que, desidratado, implora por água.

Capturado, subvertido e, finalmente, derrotado o movimento de Junho, a burguesia deu-se momentaneamente por satisfeita, e o jogo seguiu no ano seguinte, em 2014, quando se combinaram espasmos da primeira e genuína fase das revéis jornadas, como as ocupações de escolas e algumas greves importantes, e o crescimento célere, embora sub-reptício, das forças da extrema-direita, que também estiveram com força nas ruas na segunda e inautêntica fase daquele inverno quente de 2013.

A intensificação vertiginosa da crise econômica e a necessidade do capital de implementar as contrarreformas, isto é, a retirada de direitos e a austeridade fiscal, numa velocidade e profundidade sem precedentes fizeram com que a classe dominante não pudesse aceitar o resultado eleitoral do final do ano de 2014 e começasse a preparar o golpe. Para a execução do mesmo, as massas conservadoras das classes médias, que desde findadas as jornadas só faziam desenvolver seus aparelhos privados de hegemonia fascistas, não tendo abandonado por um segundo sequer a sua "guerra cultural" contra a esquerda, foram novamente requisitadas pelo andar de cima, de modo a servir como base social que justificasse o impeachment (Demier, 2017).

Com o golpe assestado, e com Temer à frente do Executivo, a ofensiva 
contra os direitos por parte de um Estado que, reduzia sua atuação nas áreas sociais, exigia cada vez mais desse mesmo Estado uma forte atuação na área judiciária-policial. E foi assim que, por meio da Operação Lava Jato liderada pelo ilibado e desafinado Moro, tal como pelas ações repressivas do aparelho estatal contra qualquer manifestação por direitos nas ruas, nas escolas e nas universidades, os aspectos bonapartistas foram sendo ingurgitados a ponto de fazer do regime político atual não mais do que uma esquálida e taciturna sombra da democracia liberal firmada pela Constituição de 1988.

O plano do capital, como se sabe, era lavar o golpe pelas urnas, posto que o projeto econômico dos golpistas deveria ser continuado em 2019, mas a partir de então por meio de algum representante orgânico e tradicional da burguesia, o qual, diferentemente de Temer, teria a legitimidade popular que as urnas costumam conferir ao vencedor do pleito. Ocorre que, permanentemente mobilizadas, as massas conservadoras das classes médias, ao longo do processo eleitoral de 2018, mostraram não estarem dispostas a depositar seus votos em qualquer um dos políticos habituais da classe dominante, afinal, "todos os políticos são corruptos" - elas haviam dito em 2013 e continuavam a fazê-lo sem rodeios durante a campanha presidencial. Desenvolvendo a crença de que poderiam elas mesmas governar diretamente o país, nossa pequena-burguesia reacionária foi buscar justamente nos tidos como "não-políticos", como os militares e juízes - os quais vinham desenvolvendo sua força na medida em que cresciam as tendências bonapartistas da democracia em crise -, os seus lídimos representantes na cena política nacional. De tão amantes da família brasileira, nossos homens de bem encontraram em uma família em especial, e mais precisamente no seu patriarca, o seu líder, o seu führer(Demier, 2019).

A alternativa neofascista estava posta, e ela incluía não só as contrarreformas neoliberais, como também, e mesmo principalmente, a negação da ciência, a rejeição às vacinas, a desconfiança do formato esférico da Terra, o fim da cultura, o desprezo pelo pensamento, o avanço da repressão à esquerda, o aumento do preconceito, a perseguição aos oprimidos e, sobretudo, como bem vem enfatizando o amigo Marcelo Badaró, uma incontrolável e freudiana pulsão de morte que parece não ser saciada, e sim estimulada conforme corpos de trabalhadores, pobres e negros vão sendo jogados pelo caminho nessa estrada do caos que o Brasil percorre (Mattos, no prelo). Diante dessa alternativa neofascista com seu sadismo indisfarçado e a outra, a da volta dos inteligentes, preparados e cordados social-democratas que haviam sido por ela depostos em 2016, a burguesia brasileira escolheu a primeira opção, e entregou o país a um degenerado capitão (Benjamin, 2020). 
É por isso, e só por isso, que chegamos a uma situação na qual, no Rio, cadáveres começaram a cheirar mal na lateral de um hospital, e, em Belém, familiares foram levados à fúria para evitar que seus doentes partam para o além. O que em meio à pandemia pode parecer - e em parte é - irracional aos olhos dos senhores da Casa Grande e de seus prepostos na televisão não é senão a mórbida tragédia a qual nos conduziu a sua oportunista e mesquinha razão. Ainda hoje, no entanto, seguem colocando o lucro acima da vida, seguem colocando os negócios acima dos josés e marias, e seguem condenando à morte aqueles que, digamos, nasceram sem herança e sem sorte. Os que naquele dia de abril arrombaram no hospital um portão foram os mesmos que, não faz muito tempo, gritaram e imploraram nas ruas por transporte, saúde e educação. Mas, os caros senhores da Casa Grande escolheram não ouvir como opção. O grande fazendeiro, o corajoso industrial, o bispo de olhos vermelhos, o ousado empreendedor comercial e o banqueiro com um trilhão, nenhum deles quis ouvir. Eles estavam todos surdos, e ainda estão.

\section{Os ratos e o barco: divisão burguesa em meio à pandemia}

Quando parecíamos nos aproximar do ápice da pandemia no país, a ala dos cruzados cátaros, os reacionários moralistas togados liderados por Moro, decidiu abandonar o barco neofascista, o que vem arrastando um amplo setor das classes médias reacionárias se não para uma oposição ao governo, ao menos para uma indiferença política apática. Os ratos, é verdade, não costumam se enganar quanto à ocorrência de um naufrágio, pois, localizados nos porões, são os primeiros a perceber a água entrar na embarcação. No entanto, diferentemente de seus congêneres no reino animal, Moro e seus albigenses não cometem suicídio ao pularem para fora da nau, já que havia botes burgueses a os esperar, como bem mostrou o convite feito por Witzel ao ministro demissionário e todo o caloroso tratamento a ele oferecido pela imprensa. Assim, como a metáfora roedora não é perfeitamente ajustável aos acontecimentos em tela, os quais permitem possibilidades que naquela são quase impossíveis, a saída de Moro não necessariamente sentenciou o naufrágio, e sim o fato de que o capitão se viu então obrigado, ou mesmo talvez tenha optado, a depender cada vez mais dos seus colegas de farda para conduzir o leme.

Enquanto isso, uma parcela dos tripulantes da segunda classe se inclina a tomar o caminho dos ratos, e saltar ao turbulento mar e se agarrar aos botes, mas fazendo pomba de leão, embora mal disfarce que, por um instante, ficou - e tal- 
vez ainda esteja - tão confusa quanto bois que ouvem ao mesmo tempo dois berrantes soarem em margens opostas do rio. Na terceira classe, uma enorme quantidade da tripulação segue sendo lançada ao mar para, por ora, distrair os tubarões e diminuir o peso da nau, o que permite também consertar certos rombos em seu casco, em especial um que não existe, mas que todos os marujos creem tal qual nas sereias, o chamado rombo previdenciário. Outra parcela desta pobre tripulação, tomada pelos cantos dessas mesmas sereias neofascistas e neoliberais, se atira voluntariamente ao mar, acreditando que os tubarões são só uns peixinhos, como lhe disse pelo alto-falante seu capitão. Outra parcela, no entanto, já começa a perceber, mesmo que lentamente, mesmo que mais devagar do que o afundar do barco, que o seu capitão só pode lhe oferecer um caixão ou o estômago de um tubarão.

Já na primeira classe, em meios aos múltiplos acontecimentos que conformam um turbilhão, fica clara a indecisão, a divisão e, por conseguinte, "reina a confusão". Praticamente toda a tripulação desta primeira classe, mesmo que não lá muito satisfeita, confiou a sua viagem, segurança e milhão às mãos do capitão, afinal, mesmo que agressivo e vulgar, era melhor ele, pensaram, do que um amigável timoneiro, mas com barba de Brutus e cheiro popular. Agora, no entanto, perceberam que essa opção por um capitão que, relativamente autônomo, decide ele mesmo o trajeto do cruzeiro, e nele inclui propositalmente rochedos e icebergs prometendo que depois destes haverá uma ilha paradisíaca com submissos selvagens desprovidos de direitos a servir a todos, é um pouco arriscada demais. Assim, alguns desses insignes senhores da primeira classe da nau podem já cogitar que, sim, os rombos no casco devem ser retificados, os pobres tripulantes devem ser jogados aos tubarões e os selvagens serviçais sem direitos serão bem vindos, mas, para tal, faz-se necessário reagrupar alguns ratos cruzados que pularam para os botes, convidar um médico que há pouco também o fez citando canções pantaneiras, e, assim, convencer os almirantes ao lado do capitão que são eles, de preferência um deles, quem devem assumir o leme do barco, de modo que o naufrágio seja evitado e o cruzeiro ultraneoliberal seja continuado. Esse almirante, claro, poderia ser também um neofascista e saudosista dos tempos em que as chibatas faziam jorrar rubras cascatas, poderia ser ele também um defensor do tempo em que os homens de um delegado - falecido, aliás, num barco - seviciavam e torturavam à vontade no porão, mas não deveria ele, Mourão, falar isso em alto e bom som. Afinal, o barco tem que ter estabilidade, e estão "todos nesse mesmo barco", mesmo que seus destinos sejam muito diferentes.

O capitão, por sua vez, ainda com o apoio discreto de altos conspícuos membros da primeira classe, e ainda sustentado por outros nada discretos entre 
ela, decidiu, então, que era a hora de jogar logo todos os pobres e velhos ao mar e ir pra cima dos rochedos e icebergs, que este caminho, o do genocídio, o dos ímpios, é o único caminho, e que ele é quem vai mostrar isso à primeira classe, pois é ele quem sabe o que é bom pra ela. Ao acelerar, assim, um barco no qual a água já pode ser vista no convés, o capitão, entre uma tosse viral e outra, estufa seu peito de atleta e diz que era é tudo ou nada, que ele não veio ido até ali para afundar, e que o barco será salvo por ele, seus filhos a bordo, os almirantes, os homens de bem e uns piratas bem experimentados em viagens de Rio de Pedras, os quais ele nunca escondeu de ninguém, muito menos da primeira classe e sua imprensa, que eram seus amigos de Escritório. Assim, agora, em meados de maio, quando redigimos estas linhas, ultrapassamos a marca das 10.000 mortes por covid-19 no Brasil.

Em meio às águas turbulentas da atual conjuntura, nas duas opções mais prováveis de serem tentadas, direta ou indiretamente, pelos egrégios homens da primeira classe para fazê-los chegar seguros em terra firme, e, de preferência, aportarem na tal ilha paradisíaca ultraneoliberal, o papel dos almirantes parece ser decisivo. Em uma delas, com a anuência dos militares e por meio das decrépitas instituições liberais, o capitão é derrubado, na outra, também com a anuência militar, ele é ainda mais empoderado. Nas duas, entretanto, a chibata vai ter lugar, uma parcela de ratos vai constar e os tubarões vão fartamente se alimentar. Em nenhuma delas, haverá quaisquer glórias para nossas vidas e lutas inglórias. Resta, assim, à terceira classe, ao menos aos que não quiserem se arriscar a nadar num mar bravio, agrupar-se, organizar-se, acender o pavio, iluminar o chão, ganhar o apoio de muita gente da segunda classe com razão e bom coração, não dar ouvido às sereias, chutar os ratos pelo caminho, e se dirigir ao convés, ciente de que, na cabine, o leme não pode estar nas mãos de ninguém escolhido pela primeira classe, sob pena de só nos restar a morte e, quem sabe, um monumento com as pedras pisadas do cais.

\section{Eu sou você, hoje: Bolsonaro e burguesia em tempos de pandemia}

Um filho é sempre um filho, mesmo que não planejado. Em certos casos, ele não é fruto só de uma noite, de um fortuito caso ou mesmo do acaso. Para alguns estratos, altos, há ainda sempre a opção de se interromper a gestação, quando se percebe o real problema e sua pletórica dimensão. Assim, talvez convenha sempre lembrar que se não fosse pelo romance impudico que a nossa 
burguesia estabeleceu desde 2015 com o plebeu neofascista, se não fosse pela incontrolável atração carnal que aquela sentiu por este durante as tétricas micaretas que terminariam no carnaval do Golpe de 2016 - onde o rufião disse que amava, porém batia - não estaríamos hoje na situação que estamos.

Em 2018, o arrivista disse que se fosse pra casar, seria nas suas condições, e a donzela burguesa, enamorada, aceitou. Dito de outro modo: sem Globo, Moro, Fux, Barroso, Carmem Lúcia, Maia, Mandetta e todos os senhores da Casa Grande, não haveria o governo Bolsonaro. Mas todas aquelas pessoas da sala de jantar estavam tão aterrorizadas com os escravos, mesmo com os mais cordatos, que se encantaram pelo feitor, pelo seu jeito firme de segurar o chicote, e o convidaram para jantar. Depois da mesa posta, e com os comensais já aguando, o jantar parece finalmente servido, mas agora o anfitrião é o feitor, é ele que comanda a prosa, limpa a boca com a toalha e cospe no chão. O prato principal, claro, somos nós.

Assim, do ponto de vista histórico, a burguesia brasileira parece só se realizar efetivamente sob Bolsonaro. O seu governo é o produto da união entre uma burguesia golpista com medo das urnas e um neofascista com excelentes chances nelas. O Bolsonaro de hoje é, portanto, o filho daquele romance, o qual, entre tapas e beijos, segue. Bolsonaro é, assim, o Pai e, ao mesmo tempo, o filho, só que o filho, neste caso, veio para trazer a verdade e propagar a palavra da Mãe, nada virgem. Uma burguesia medrosa, apaixonada por um líder neofascista, deu à luz a este governo de traços bonapartistas que, para protegê-la, intenta subverter o seu próprio regime, em nome do Pai. Mas o espírito de um é, também, o espírito de todos, embora os três, neofascismo, burguesia e governo, ainda são sejam um só. Ainda.

A morte apregoada por Bolsonaro é o máximo que a vida da sociedade burguesa pode hoje oferecer. Pode-se dizer, desse modo, que a prática autocrática da nossa classe dominante encontrou, enfim, sua expressão teórica no bolsonarismo reinante. A ancestral e intermitente violência burguesa é vocalizada por Bolsonaro de forma impudente. Este fala o que aquela sempre fez, mas nem sempre falou, porque nem sempre pôde falar, porque nem sempre pode falar. A burguesia é, portanto, o porquê de Bolsonaro. Ele faz, e agora fala, por ela, para ela. A contumaz aversão empírica da nossa burguesia à arte, à cultura e à ilustração parece agora finalmente condensada na teoria bolsonarista e seu ódio à teoria, sua ode à ignorância, seu culto ao simplório, e seu amor ao bruto - e, claro, às brutalidades. A política sempre pragmática da nossa classe dominante, isto é, sua rejeição prática à teoria política, ou, se quisermos, à política como teoria, se exprime agora na teoria política da antipolítica de Bolsonaro, cujas ideologias, 
programas e projetos se realizam na prática justamente na medida em que verbalmente negam ser ideologias, programas e projetos. O característico desprezo ordinário da burguesia brasileira pelas formas democráticas é o conteúdo contido na extraordinária forma da retórica autoritária bolsonarista.

O permanente horror à vida dos de baixo por parte dos de cima é agora revelado quando o próprio horror, no poder, conduz, de cima, à morte os de baixo. Com Bolsonaro, a pandemia se torna o clímax histórico da burguesia. Ao fim e ao cabo, Bolsonaro é a burguesia voando em céu aberto, é o seu desejo nem tão secreto, é a sua já sabida verdade revelada, é a libertação formal e exótica de todo o seu conteúdo letal na história. Assim, a necessária luta contra Bolsonaro só poderá verdadeiramente pôr fim a nossa agonia se for tomada como um momento necessário da nossa verdadeira libertação em relação à burguesia.

\section{Agora e depois da pandemia}

O governo brasileiro hoje se divide entre os que desejam a morte de milhares de pobres pelo vírus, e os que, com o mesmo desejo por tais mortes, não acreditam sequer na existência do tal vírus. Foi a gente assim, a fanáticos do mercado e a discípulos de um astrólogo, que a nossa classe dominante, seus juízes, seus congressistas e sua imprensa entregaram o comando do país. Hostil à democracia, como também à poesia, já disse o poeta Agenor, nossa burguesia parece se realizar na pandemia e, no seu íntimo, deve gozar com a nossa dor.

Se o Deus das escrituras falava em parábolas, pois muitos na Terra, cumprindo a profecia de Isaías, já apresentavam um insensível coração, o deus mundano, o deus das falcatruas, o insensível Deus Mercado de Guedes, Merval e Leitão, só tem hoje como profecia aos trabalhadores uma cova ou um caixão. Pelos vidros das enfermarias, os pobres se despedem dos seus pobres, os pretos, quase todos pretos, dos seus pretos, as precarizadas famílias dão um precário adeus àqueles por quem Deus, não o celestial, mas o do capital, nunca olhou. É gente humilde, dá vontade de chorar, e muitos vão mesmo chorar até isso passar. Nós vamos chorar, e devemos chorar, de modo que sigamos a lutar. Agora e depois da pandemia. Já outros, outros poucos, discutem demissões e a volta à "normalidade" na sala de jantar, e estão muito ocupados em nascer e morrer, embora não devam em quantidade morrer por conta do vírus que ajudaram a trazer. Lágrimas e direitos não nos podem agora dispensar. São seiscentos reais, com fila, e olhe lá! 
Para milhares hoje no Brasil bá choro e ranger de dentes, mas para alguns poucos isso pouco importa. O show - de horrores - não pode parar, a economia não pode parar, a retirada de direitos o congresso deve o mais rápido possível aprovar! - é isso o que clamam nossos comentaristas da televisão, nossos deputados do centrão, nossos pastores sem religião e os genocidas no comando da nação (Behring, 2020).

Talvez nunca os lados tenham ficado no combate tão claros, talvez nunca o antagonismo entre as classes sociais tenham assumido formas tão virais e letais, talvez nunca trabalho e capital tenham se feito representar tão limpidamente entre bem e mal, entre a morte severina de pedreiros severinos e a lucratividade daqueles poucos de herança e sorte, entre os que morrem defendendo a vida e os que vivem glorificando a morte. E entre a vida e a morte não há meio termo, salvo o de uma vida vegetativa, uma vida morrida, uma morte em vida. Se você hoje está do lado da vida, saiba que está entre aqueles cujo objetivo principal, a própria vida, só poderá ser alcançado numa luta de vida e morte contra a nossa mortífera burguesia.

O único jeito de frear essa carnificina é derrubar, o quanto antes, Bolsonaro, Mourão, Guedes, e todos os que fazem do Brasil um imenso cemitério para trabalhadores, negros e todo o tipo de gente que nunca foi de fato ouvida por nenhum ministério. Agora, é o lucro ou a vida, a vida ou a morte, e chegou a hora de decidirmos, nós mesmos, a nossa sorte. Quem vai viver e quem vai morrer, não podem ser a bolsa e Bolsonaro a escolher. Também não podem ser Maia, Dória, Witzel e toda essa gente que com o povo só tem desprezo. Façamos nós com as próprias mãos tudo que a nós nos diz respeito, e vocês, senhores, que hoje sobre corpos só fazem lucrar, pagarão e é dobrado cada lágrima nesse nosso penar. Lutaremos, nós mesmos, pela vida, por toda vida e por toda a vida. Agora e depois da pandemia.

\section{Referências}

BEHRING, Elaine. Escassez é um mito vendido caro: sobre o orçamento público em tempos de pandemia. Esquerda Online, 19/03/2020.

BENJAMIN, Cid et al. O ovo da serpente: a ameaça neofascista no Brasil de Bolsonaro. Rio de Janeiro: Mauad X, 2020.

BOITO Jr., Armando. Cena política e interesse de classe na sociedade capitalista - comentário em comemoração ao sesquicentenário da publicação de $\mathrm{O}$ dezoito brumário de Luís Bonaparte. Crítica Marxista, São Paulo: Botempo, n. 
15, p. 127-139, 2002.

CISLAGHI, Juliana Fiúza. e DEMIER, Felipe. (orgs.). O neofascismo no poder (ano I): análises críticas sobre o governo Bolsonaro. Rio de Janeiro: Consequência, 2019.

COUTINHO, Carlos Nelson. Gramsci: um estudo sobre seu pensamento político. Rio de Janeiro: Civilização brasileira, 1999.

DEMIER, Felipe. Crônicas do caminho do caos: democracia blindada, golpe e fascismo no Brasil atual. Rio de Janeiro: Mauad X, 2019.

. A dialética da democracia blindada no Brasil. Rio de Janeiro: Mauad X, 2017;

. E HOEVELER, Rejane. (orgs.). A Onda conservadora: ensaios sobre os atuais tempos sombrios no Brasil. Rio de Janeiro: Mauad X, 2016.

FERNANDES, Florestan. A revolução burguesa no Brasil: ensaio de interpretação sociológica. Rio de Janeiro: Zahar, 1975.

FONTES, Virgínia. Que hegemonia? Peripécias de um conceito no Brasil. In:

. Reflexões im-pertinentes. História e capitalismo contemporâneo. Rio de Janeiro: Bom Texto, 2005.

.O Brasil e o capital-imperialismo. Teoria e história. Rio de Janeiro: EPSJV/UFRJ, 2010.

GRAMSCI, Antonio. Cadernos do cárcere. 3. ed. Rio de Janeiro: Civilização Brasileira, 2007, volume III.

HOEVELER, Rejane; GEORGE, Danilo. Pandemia e golpismo: a tempestade perfeita no Brasil. Esquerda Online, 19 mar. 2020. Disponível em: < $\underline{\text { https: // }}$ esquerdaonline.com.br/2020/03/19/pandemia-e-golpismo-a-tempestade-perfeita-no-brasil/>. Acesso em: 2020.

IANNI, Otávio. Apresentação. In:MARX, Karl. O 18 brumário de Luís Bonaparte [e Cartas a Kugelman]. Tradução de Leandro Konder e Renato Guimarães. 4. ed. Rio de Janeiro: Paz e terra, 1978.

MATTOS, Marcelo Badaró. Governo Bolsonaro: neofascismo e autocracia burguesa no Brasil. São Paulo: Usina editorial (no prelo).

MARX, Karl. O Capital: crítica da economia política. São Paulo: Abril Cultural, 1984, livro I, tomo 2 
O 18 brumário de Luís Bonaparte. In: MARX, Karl. O 18 brumário de Luís Bonaparte [e Cartas a Kugelman]. Tradução de Leandro Konder e Renato Guimarães. 4. edição. Rio de Janeiro: Paz e Terra, 1978.

e ENGELS, Friedrich. O Manifesto Comunista. São Paulo: Boitempo, 1998.

NETTO, José Paulo. Uma face contemporânea da barbárie. Comunicação apresentada no III Encontro Internacional Civilização ou barbárie. Serpa, outubro/novembro de 2010.

POULANTZAS. Nicos. Poder político e classes sociais. Porto: Portucalense, 1971, 2 volumes.

. Fascismo e Ditatura: A III Internacional face ao fascismo. Porto:

Portucalense, 1972, 2 volumes.

O Estado, o poder e o socialismo. Rio de Janeiro: Graal, 1980.

SAES, Décio. Democracia e capitalismo no Brasil. Balanços e perspectivas.

In:__ República do Capital: Capitalismo e processo político no Brasil.

São Paulo: Boitempo, 2001.

SINGER, André. Raízes sociais e ideológicas do lulismo. In: Novos Estudos Cebrap, n. 85, 2009.

TROTSKY. León. Aonde vai a França?São Paulo: Desafio, 1994.

. Revolução e contra-revolução na Alemanha. Lisboa-Porto-Luanda:

Centro do Livro Brasileiro, s.d. 
